\title{
WOMEN, VIOLENCE AND EDUCATION: A CASE STUDY OF ESFAHAN PROVINCE, IRAN
}

\section{Mohammad Reza Iravani*}
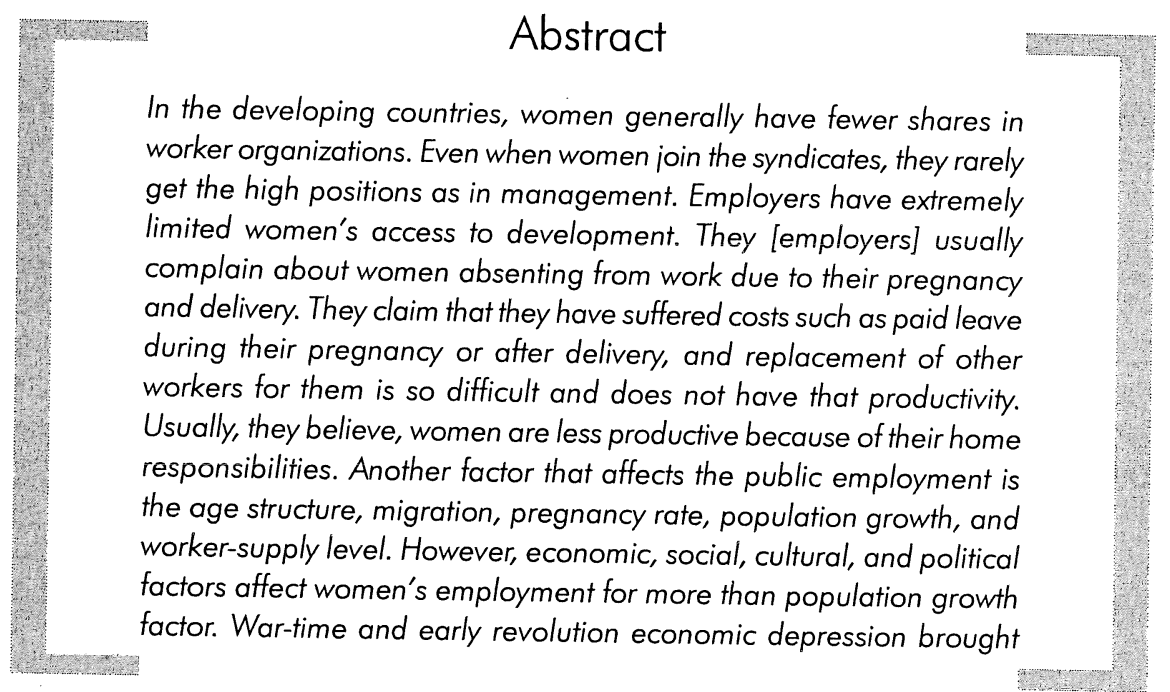
* Lecturer at Islamic Azad University Of Khomeinishahr (Iran), Islamic Azad University
Khomeinishahr Branch, Daneshiou Blvd, qqq200000@gmail.com 
about changes in the economic system of the country and resulted in transitions in the work market. These transitions and economic depression seriously limited industrial production and productive employment where women's employment was quantitatively and qualitatively affected.

Keywords: Violence, Education, sexual abuse, rape.

\section{Introduction}

In its specific concept, modern anthropology refers to human knowledge and/or its function or applicability whose common theme is 'human being' who has physical, mental, and cultural characteristics or possessions. C. Ford, who is one of the traditional anthropologists, maintains that in any culture, men are dominant, aggressive, and women give a birth to babies and rear them and their family functions are never changeable. It does not seem that technological changes and awareness of gaining equality between the two sexes regarding their functions will result in real changes. The differences that originate from their productive functions and roles impose a great gap between the two sexes and since the family can stay alive, they are limitations in this change. He maintains that giving freedom to women prevents them from having sexual relationships and bearing children. (3)

\section{Women: Cultural, Social Violence}

One of the grounds of which women must be aware to effectively participate in the country's development as dynamic people in individual and social life for better and more logical decisions is the political awareness. Most of the political awareness that is so extensive in different parts of one's life can serve as a strong motivation or stimulant and help him do some extraordinary work so that he can act far better than his usual accomplishments. The work that is done with awareness guarantees exact implementation and brings about desirable results. Zanianizadeh says, "Defending women's rights must be by informing them of the exploitation they are entangled at home that is the main cause of their underdevelopment in economic, cultural, and political grounds. Here, housework that has been labeled as 'womanly work' for some traditional reasons is a big barrier to women's participation in economic, social, cultural, and political squares. Hence, to get rid of this barrier, women must be more conscious of their rights. In many related sources, there is an introduction to women's awareness of their rights by emphasizing and relating it to education. When an individual gets educated, he/she has the opportunity of having 
access to scientific findings and divine law more precisely and without being distorted and then can thoroughly decide on the development programs and be more prepared.

\section{Functionalists and Women}

Functionalists maintain that social system enjoys a balance. This helps the society be unified. In their opinion, whole and details are mixed with each other and have a unified identity. The functionalist foundation is based on the fact that all social traditions, relationships, and institutions and their survival depend on a function which they have undertaken in asocial system (2). Their viewpoint on women is also a function of their school of thought. They hold that women play an emotional role in families. They are breadwinners. Men are aggressive, leaders and problemsolvers, creative, and productive. Parsener believes that women play an essential role in the present era and that any likely change[s] in their role equals a disaster. He maintains that giving equal significance and opportunities to both the sexes is not compatible with the positive integration of a family, and their separation to maintain the social structure and status quo is the primary objective of the functionalists that feel necessary.

Sociologists require women to adapt themselves with the status quo, and they believe that women's getting aware of their deprivation would disturb their functions and present standing. Nevertheless, their present dissatisfaction with their obedient functionality in the family and the discrimination applied to their roles outside the family has made them seek or claim their rights. Functionalists believe that assigning political and economic functions to women causes functions of the society to demolish. On the other hand, two political advocates of women's rights and freedom maintain that women's participation in political affairs has been distorted because the poor political situation in present era is due to the lack of women's participation and requires their contribution. In his book 'Political Life', Robert Leen says, "Women's participation in political affairs or any kind of activity outside home is in fact stealing from familial opportunities." (1)

\section{Freudian Psychology and Women}

Freud holds that the essential of human existence is not self awareness or consciousness but unconsciousness. It is not wisdom but love, affection and excitement. Unconsciousness is a true mental reality. Unconsciousness is independent of consciousness because it is able to understand the world. Two conservative pro-Freudian psychologists, Marina Farheinam and Ferdinand 
Landburg, claim that women's organisms are not capable of the sensations and feelings men can get from success, and they [women] must have less education and literacy. Women must not try to succeed, nor must they strive to participate in political activities. In their opinion, women are naturally born eternally obedient and passive, while men are naturally born aggressive, stubborn, and dominant and there is no change possible because men and women's fundamental mental characteristics are biologically defined and are not subject to change.

\section{The Theory of Occupational Market Decomposition}

This theory considers occupational market as a set which human obstacles have divided it into different clauses and parts. In each clause, neo-classic principles are vividly seen. One of the most famous theories is the mutual occupational market that [the theory] distinguishes between two jobs. The first group includes those that pay well, provide security, and opportunities for advancement, and the second group of jobs refers to those which pay less, and secure less opportunity for advancement. In the first group, workers' stability at work is significant to the employer, and women show more mobility which implies that they can be recruited to the second group of jobs. Hence, even if qualifications are equal, men are more likely to get employed in the first group of jobs than women where there are more chances of promotion, vocational education and training for men than for women.

\section{Primitive Societies}

A group of historians maintains that it was during the era of Stone Age where work was differently assigned to and divided between men and women. Men went hunting and women and children collected fruits and plants. The archeologist P. F. Marco says, "Neanderthal instruments belonged to both men and women. The sharppointed means were men's and women handled scratching and cutting instruments. It is worth mentioning that one of the reasons why women got used to house holding and farming was men's defensive responsibility that they had in combating with the ethnic enemies and had no time to spend at home or on the farm. This was the first work division between men and women in those primitive societies, which was based on hunting and collecting the hunt.

With the advancement of making instruments and the new approaches of working, social conditions were affected, too. In early Paleolithic era, women enjoyed the highest standing and people's position was evaluated by virtue of economic activities they did. In these societies, work was collectively done and men just hunted. Women had no authority over men and they could not exploit them but were exploited, and 
they were mostly busy farming. Clans were matriarchal in the agricultural communities, and in the animal husbandry societies, the work of husbandry was discharged by men. With the appearance and use of ploughshare, agriculture was totally assigned to men, and they started to collect money and asset where privatization developed. Interior government and armed men to support the rich people's sovereignty over slaves and ordinary people (peasants) appeared, slavery emerged, and women were disparaged. Later the feudal system developed and no longer was anyone the holder of another as a slave, but peasantry (system) spread out. Aristocracy was of two types: Religious and Non-religious. Churches did disparage women. Women did any kind of agriculture except plowing.

In the early $13^{\text {th }}$ century, the promotion of capitalism helped the bourgeois wealthy women's relationships. Because of their economic foundation reinforcement, though looked upon as the low class people, these women were considered as independent people by entering the trade-market. In feudal societies, though women played a great economic role, they were regarded as subordinates and slaves legally. With the expansion and development of trade and lifestyle, economic and social standing improved. In the US and Western Europe, there were revolutions which resulted in capitalism. The slogans of "Freedom and Equality" in the French and American revolutions helped women get aware of their rights, and they tried to campaign to get them [their rights]. Women had not yet got as many of their rights as they desired until mid-1 $9^{\text {th }}$ century. With the campaigns they had, they could secure the right of trading in 1850 and 60s and in the 1920s, they could get the right of voting, and gradually in several years, they could get other rights of equality with men.

\section{Cultural Barriers}

The content analysis of primary textbooks carried out by the Cultural and Humanities Research Center indicate that most of the names used in the textbooks are men's names both before and after the Islamic Revolution. For every four male names, there is only one female name, and, more interestingly, this relationship fades as children go to higher classes. The older the children get and the higher classes they enter, the less they encounter female names. In fact, female names are totally eliminated. In pre-revolution textbooks, women's pictures were mostly economically and socially based, but the post-revolution ones are morally and religiously designed. Women's pictures on exercising and playing sports have been completely eliminated. The activities emphasized in the primary textbooks are more manly-dominant including the jobs men do outside homes. With the higher standards, the same method, employed for female names, is applied. Hence, in the socialization period, according to the theories of modernizing children to accept the current values of 
the society where they start to understand and appreciate right and wrong, sex equality and equal opportunities for both men and women must be emphasized. However, the post-revolution textbooks are in practice disparaging those values and in effect advocating the segregation of women from the society. This has in fact caused the women do devalue themselves and feel that they are less than men and less important than them. Therefore, they automatically surrender themselves to patriarchal system in the society. They are hardly motivated or even allowed to strive to promote their knowledge and information on their individual family and vocational rights. After the revolution, women came to this conclusion that patriarchal thought was dominant in their work environment, and since then they have been disappointedly concerned that they can never get a post in the society, and it is the absolute right of men to mount on the post-steps. Competitiveness and motivation are dead in them, and they are only working to earn a living and not to lose their little pension they will get after retirement. What a disposition! They do not know advancement, high posts, and administrative promotion. Only through their hardworking, diligence, and perseverance have they been able to maintain occupational standing and protect it from the radicalisms, but, still, there is a big problem and, in fact hindrance, in their way of participation: Anti-women participation propaganda. Under the sever pressure of propaganda and restrictions, women are most hesitant and dubious about their righteousness of their behavior in the society.

They do not know how and by what standards their behavior is evaluated in an atmosphere where they work with men! They are always stressed out about what to do, what not to do, what to say, and what not to say! This causes the women to keep silent at work ad not to participate in social, political, and even religious discussions and argumentations. This absolutely wrong impression and interpretation in the jurisprudential references where women have no right to participate in social and political affairs is a big cultural barrier to their cheerfulness. They are never happy and jovial: they have depression, have developed hunch from suppression, and suffer from languidness. This is also a big problem even for the religious families by not motivating their daughters to take up a responsibility or job in their prospective life.

\section{Conclusion}

In a study it is felt that the effect of factors such as age, literacy, kind of activity, job experience, the extent of the possession of farming land, etc. on the educational needs were studied. In this study the time, place and suitable season of education from the viewpoint of rural women were also determined. This study is a descriptive research, the survey kind, in which 250 rural women from the four towns of Isfahan, 
Najaf Abad, Naeen, and Samirom were selected by accidental and stratified sampling methods and the required data were collected through two questionnaires testing the needs and activities and a questionnaire testing the degree of awareness by direct interview. The results of the study showed that the rural women have little knowledge about preparing the ground for cultivation and feel no much need for education. At the planting stage their main need is the education about the correct way of BOJARIE BAZR and the selection of the healthy and suitable seeds. They also need to know the correct way of disinfecting seeds and the right amount of the use of seeds. The findings showed that at the harvesting stage of farm products there is a significant difference between the mean of educational needs at different levels of education. There is also a significant difference between the means of the educational needs of rural women at different classes of having the experience of how to obtain and maintain transforming industries. However, there is no significant difference between the different stages of planting, harvesting, and maintaining. It was also found that there is a significant difference between the agricultural activity of the rural women and the extent of their educational need on obtaining and maintaining of the transforming industries. There is a significant difference between the extent of the activity of the rural women in the different stages of the production of the farm products and the extent of their educational needs.

\section{References}

Arora, R.C. (2001): 'Tribal Poverty, S. Chand Company Ltd.: New Delhi.

Pandey, (2001): 'Tribal Development : Critical Issues', Indian Journal of Economic Development Vol. 12, No, 09 , pp. 23-41

Kakker (2001): Tribal Issues in India, Journal of Asian Development Vol. 10, No. 3 pp. 45-59

Mohanty, P.K 2002. "Development of Primitive Tribal Groups in India," Kalpaz Publication: New Delhi

Makhan iha, 1995, "An Introduction to Indian Anthropology," Vikas Publishng House, New Delhi Patel, M. L. 1994. "Development and Dualism of Primitive Tribes", M.D Publications: New Delhi Singh. B, (1977). "Tribal Development at Cross Road" Man In India. 57(3): 229-247.

Verma, R C1995. "Indian Tribes Through the Ages," Publication Division, Ministry of I and B, Government of India. 